University of Chicago Law School

Chicago Unbound

Journal Articles

Faculty Scholarship

1979

\title{
Accelerated Depreciation: A Proper Allowance for Measuring Net Income
}

Walter J. Blum

Follow this and additional works at: https://chicagounbound.uchicago.edu/journal_articles

Part of the Law Commons

\section{Recommended Citation}

Walter J. Blum, "Accelerated Depreciation: A Proper Allowance for Measuring Net Income," 78 Michigan Law Review 1172 (1979).

This Article is brought to you for free and open access by the Faculty Scholarship at Chicago Unbound. It has been accepted for inclusion in Journal Articles by an authorized administrator of Chicago Unbound. For more information, please contact unbound@law.uchicago.edu. 


\title{
COMMENTS
}

\section{ACCELERATED DEPRECIATION: A PROPER ALLOWANCE FOR MEASURING NET INCOME?!!}

\author{
Walter J. Blum*
}

In a recent article in the Michigan Law Review, Douglas A. Kahn strives to demonstrate that, given the general postulates of the federal income tax, accelerated depreciation is a proper allowance for measuring net income and should not be classed as a tax expenditure. ${ }^{1}$ His defense of accelerated depreciation is unusual if not novel, and his presentation is engaging. For anyone who shares my view that most tax expenditure stuff is mainly political rhetoric and who is sympathetic to my position that our tax system is far too harsh in taxing income from capital investments, a new plug for accelerated depreciation is not unwelcome. The Kahn analysis, I confess, can be seductive: there is comfort in being assured that accelerated depreciation, usually advocated to encourage greater investment in certain types of assets, is consistent with the neutrality principle for taxing income. I write, however, not to praise the effort of an ally but to show why it is misleading - or just plain wrong.

First a word about the notion that I refer to as the "neutrality principle" in designing the base of an income tax. The principle is not very refined or profound. It perhaps is best grasped as a guide for distinguishing between rules that can be justified by an articulated broad concept of personal income during the reporting year and rules that go beyond such a broad concept and are more favorable to those taxpayers who are affected. The former type of rules might be regarded as consistent with the neutrality principle; the latter type might be viewed as being justified not on tax principles but on economic or social considerations that lie outside the broad conception of income. In recent years these more favorable rules are often labelled "tax expenditures" - that is, they are seen as subsidies disbursed by government through the income tax system.

* Wilson-Dickinson Professor of Law, University of Chicago. B.A. 1939, J.D. 1941, University of Chicago. - Ed.

1. Kahn, Accelerated Depreciation - Tax Expenditure or Proper Allowance for Measuring Net Income?, 78 MICH. L. REv. 1 (1979). 
Another preliminary note is in order. Accelerated depreciation has frequently been defended on the ground that, in a noninflationary world, machinery and buildings usually produce greater net income - meaning revenues less expenses - in their earlier years of use. Because net earnings decline, such assets lose value faster in the earlier as compared to the later years in which they are in service. Kahn does not rest his position on this relationship either as an assumption or as a fact. On the contrary, the model for his analysis of cost recovery or depreciation deductions is an asset that yields a steady stream of annual net income during its use by the taxpayer. It is important to keep this somewhat narrow foundation in mind.

Kahn begins his analysis of cost recovery by examining payments to annuitants. The question addressed is one of theory: putting aside the actual tax rules, which seem to reflect special social or political concerns about the treatment of annuitants, how are the relative magnitudes of the cost recovery component and the interest component in level payments received by an annuitant to be determined? This challenge is posed by the existence of an income tax that, stated over-generally, reaches only the interest factor and leaves untouched the cost recovery factor. An annuitant not subject to an income tax would be unconcerned with the question as framed - to him all dollars in a particular payment would be exactly alike.

To illustrate the central income tax issue, Kahn deals with a three-year annuity contract, purchased for a lump sum, entitling the annuitant to one dollar at the end of each of the three years regardless of whether he survives. ${ }^{2}$ If the annuity writing company computes premiums on the premise that it will pay six percent interest, compounded annually, on funds available to it, then the lump sum price of the annuity will be approximately $\$ 2.67$. This amount is the present value of one dollar per year, receivable at the end of each of three years, discounted at six percent. The essence of the transaction is that the annuitant is giving up $\$ 2.67$ now to receive a total of $\$ 3.00$ over the next three years - which means that he will be getting 334 in aggregate for allowing the annuity company to use his funds. The tax question is one of timing: when is the $33 \notin$ to be reflected in the annuitant's income for tax purposes?

There is, it should be noted, a mirror image of this question when the transaction is seen from the perspective of the annuity company. If interest payments are deductible in computing taxable income of the annuity writer, while repayments of funds invested by annuitants

2. Id. at 23 . 
are not, then the company must determine how the $33 \notin$ interest factor in the hypothetical contract is to be spread over the three years.

The appropriate theoretical resolution of the issue, from the viewpoint of both the annuity writer and the annuitant, is beyond doubt. Inasmuch as the company is paying interest for use of a sum that diminishes over time, the interest calculations must be geared to the time spans for which funds are actually available to it under the contract; for this reason the company must assume that, whatever the rate of interest built into the contract, the interest charge accrues on a periodic basis - refined possibly to a daily calculation. ${ }^{3}$ In the hypothetical case the company has the full $\$ 2.67$ available to it for the first year, about two thirds of that amount or $\$ 1.78$ for the second year, and about one third of that amount or $89 \$$ for the third year. The total of 334 interest payable over the three-year term of the contract would be accrued or apportioned in roughly the same pattern. About three sixths or 164 would be charged to first-year operations, two sixths or $11 \%$ to second-year operations, and the balance of one sixth or $6 \$$ charged to the final year.

In tabular form the result would be as follows:

\begin{tabular}{cccc} 
At close of year & $\begin{array}{c}\text { Total } \\
\text { Amount } \\
\text { Paid }\end{array}$ & $\begin{array}{c}\text { Investment } \\
\text { Returned }\end{array}$ & $\begin{array}{c}\text { Interest } \\
\text { Paid }\end{array}$ \\
\hline \hline 1 & $\$ 1.00$ & $84 \uparrow$ & $16 \leftarrow$ \\
\hline 2 & $\$ 1.00$ & $89 \uparrow$ & $11 \mathrm{c}$ \\
\hline 3 & $\$ 1.00$ & $94 \uparrow$ & $6 \mathrm{c}$ \\
\hline \hline & $\$ 3.00$ & $\$ 2.67$ & $33 \leftarrow$
\end{tabular}

This pattern is quite familiar to borrowers who repay a mortgage loan in level amounts over the period of the indebtedness. The mortgagor in effect is in the position of the annuity writer in the hypothetical case in that he is paying a uniform rate of interest on a diminishing sum made available to him by the mortgagee. If the debtor borrows $\$ 2.67$ to be repaid in equal installments of one dollar at the end of each of the next three years, then his cost of borrowing will be approximately six percent on an annual compounded basis; moreover, the interest component of these dollar payments will decline in the same pattern as that seen in the annuity tabulation.

All these thoughts, widely accepted, are captured by the notion of sinking-fund accounting. Both the mortgagor and the annuity writer are in a position resembling that of someone who periodically must pay a constant amount into a fund which, augmented by interest at an assumed uniform rate, will reach the total sum needed to dis-

3. See id. at 23 n.82. 
charge a definite obligation on a certain date. The first-year contribution obviously will earn a greater amount of interest during the duration of the fund than will the second-year contribution, the second-year contribution will earn more than the third, and so on through the years.

Kahn acknowledges these considerations, but goes on to argue that there is another way - equally sound - for analyzing level annuity payments. The hypothetical three-year annuity, he asserts, can be viewed not as a single contract but as three separate contracts. ${ }^{4}$ Under one contract the annuity company agrees, upon immediate receipt of the premium, to pay the annuitant one dollar at the end of a year; under another contract, again upon immediate receipt of the premium, to pay one dollar at the end of two years; and under the third, likewise upon immediate receipt of the premium, to pay one dollar at the end of three years. If the assumed rate of interest to be paid on funds made available to the annuity writer is six percent compounded annually, then the cost of the first contract is one dollar discounted for one year at six percent, or $94 \$$; the cost of the second is one dollar discounted for two years at six percent, or $89 \$$; and the cost of the third is one dollar discounted for three years at six percent, or $84 \$$. The total cost of the three contracts remains $\$ 2.67$ - a result to be expected inasmuch as the three contracts are postulated to be equivalent to the single hypothetical contract.

From the viewpoint of the company, the shift from one contract to three contracts will not change the result: under the assumed conditions the duration for which funds are available to it will remain exactly the same. How, then, is it possible that the shift might alter matters for the purchasers of annuities?

The difference, according to Kahn, turns on application of socalled accounting rules that are generally accepted under our income tax..$^{5}$ Almost all annuitants are persons who for tax purposes report their affairs on the cash receipt method (which, be it noted, is not predicated on standard accounting principles but is only a reporting method). Assuming that the usual cash method rules are brought to bear, the annuitant owning the three contracts would report interest on each as the payment came due. In tabular form his reporting position would be this:

4. Id. at 24.

5. Id. at 24-25. 


\begin{tabular}{|c|c|c|c|c|c|}
\hline & $\begin{array}{l}\text { Contract } \\
\text { Number } \\
\end{array}$ & Cost & $\begin{array}{c}\text { Amount } \\
\text { Received }\end{array}$ & $\begin{array}{c}\text { Interest } \\
\text { Received }\end{array}$ & $\begin{array}{c}\text { Return of } \\
\text { Capital }\end{array}$ \\
\hline First Year & 1 & 944 & $\$ 1.00$ & 64 & 940 \\
\hline Second Year & 2 & $89 \mathbb{c}$ & $\$ 1.00$ & 114 & 894 \\
\hline Third Year & 3 & $84 c$ & $\$ 1.00$ & 164 & 844 \\
\hline & & $\$ 2.67$ & $\$ 3.00$ & 334 & $\$ 2.67$ \\
\hline
\end{tabular}

The result is a complete inversion of that reached under the sinking-fund analysis. The interest component in each dollar received grows rather than diminishes over time. Indeed, the new tabulation is merely the earlier sinking-fund tabulation turned upside down.

Having considered the treatment to be accorded the three separate contracts, Kahn goes on to assert that the hypothetical single contract can be analyzed as though it consisted of the three individual contracts. ${ }^{6}$ It then follows, he argues, that the inverted sinkingfund pattern is an acceptable way for a cash method taxpayer to report annuity income. This conclusion might be extended to level installment payments of a loan where borrower and lender have not specified an allocation between the interest factor and the repayment of principal factor. In that event the interest component would grow rather than diminish as time went by.

Two flaws seriously undermine this approach.

It is highly unrealistic to assume that a single annuity contract for three years is equivalent to three separate contracts for one year each. Think of borrowing funds from a bank. Assume that the prevailing rate of interest on an immediate three-year loan is six percent. This does not imply that the prevailing rate for an immediate one-year loan is six percent, to say nothing of the rate for a one-year loan to be made a year from now or a one-year loan to be made two years from today. Recent events in financial markets underscore how unlikely it is that these rates will be identical. A similar diversity of interest rates might be expected to prevail in pricing term annuities that start at different dates.

The other flaw lies in the treatment of the cash accounting method. That method, stated generally, allows taxpayers to defer the reporting of "earned" interest (or other types of income) until a cash receipt is in hand. The deferral is acceptable for two main reasons - administrative ease and financial convenience. An overwhelming majority of individuals in fact keep their records on the basis of cash receipts and disbursements. Additionally, many taxpayers would feel unreasonably burdened if they were compelled to accrue

6. Id. 
"earned" items and to pay taxes on them before receiving cash or being in a position easily to translate the income into cash. Neither of the considerations applies in the annuity situation. Under either the sinking-fund or the inverted sinking-fund approach to determining the allocation of aggregate interest among annual periods, the annuitant must make (or rely on) a calculation that goes beyond reporting solely on the basis of cash received. And should the annuitant be required to use sinking-fund reporting, he already would have the dollars in hand that reflect the amount of interest he reports for tax purposes. In the illustration, the $16 \$$ interest in year one resulting from a sinking-fund calculation is amply covered by the one dollar received by the annuitant at the end of that year.

Even if the annuitant were to buy each of the three separate policies from a different company, Kahn's pronouncement on the cash receipt method of reporting is an unguarded overstatement. He leaves the impression that there is something about the cash method that puts a seal of approval on deferring the reporting of interest in the imagined divided contract situation. To be sure, under existing law the interest credited to annuitants on deferred contracts is not reported until the annuity commences to pay out (just as it is true that under existing law annuitants are not subject to a sinking-fund calculation of interest, but are given the benefit of a constant ratio between interest and cost recovery over the years of receiving payments). The temporally split contracts envisaged by Kahn, however, are less like standard deferred annuities and more like non-interest bearing debt obligations issued at a discount. In paying 844 to receive one dollar three years later, for example, the purchaser is investing $84 \mathbb{4}$ at six percent interest for three years. The $16 \notin$ difference between cost and expected receipt is tantamount to an original issue discount which substitutes for periodic interest payments. Tax law has long required those who hold certain types of obligations issued at a discount to amortize that discount as interest attributable to each of the intervening years between issuance and maturity. The law currently is wrestling with a similar question regarding nontransferable short-term certificates of deposit which mature in the year after issuance. An impartial observer surely would be sagacious in thinking that the gimmickry of buying a cascading series of annual deferred annuity contracts would rather quickly be defeated by a rule requiring an accrual of interest. Cash receipt reporting, after all, is based on a need to accommodate "normal" or "businesslike" transactions. Nothing suggests that it was intended as a carte blanche 
ticket to avoid taxes by way of arrangements that have no purpose other than tax minimization.

This is not the end of the matter, however. Kahn, in developing his thoughts, is primarily interested in defending accelerated depreciation on the neutrality principle. To understand that defense better, one perhaps might provisionally accept his conclusion about taxing the interest element in an annuity - wrong though it appears to be.

The course by which he gets from annuities to accelerated depreciation is instructive. The connecting link seems to be the treatment of prepaid expenses. Kahn presents the case of a five-year business fire insurance policy on which the entire premium is paid in advance. ${ }^{7}$ If the annual premium is $\$ 1,000$, and if the contracting parties agree on a ten percent compounded rate of discount for prepayment of coverage for future years, then the discounted total premium for all five years will be $\$ 4,169$. Treating the arrangement as five separate one-year policies, the paid-in-advance premium for the first year will be $\$ 1,000$, while the discounted premiums will be $\$ 909$ for the second-year coverage, $\$ 826$ for the third, $\$ 751$ for the fourth and $\$ 683$ for the last. Pursuant to the Kahn analysis, the purchaser should be able to deduct these differing amounts in the particular year to which the coverage pertains. The result once again is an inverse sinking-fund pattern - high deductions for expenses in early years, low deductions for expenses in later ones. Obviously the outcome depends on the assumption that, for tax purposes, the insured never need take into account the imputed interest for which he is given credit by the insurance company in computing prepaid premiums.

It almost goes without saying that the weakness of this position mirrors that earlier noted in the annuity analysis. Realistically, a prepaid five-year insurance policy is not equivalent to a series of five prepaid one-year policies. In many instances it is not possible for the insured to derive the rate or rates of discount implied in the prepayment arrangement because the insurer's assumptions with regard to pricing future insurance risks are not revealed. But even if imputed interest could be computed and then were taken into account, the case for using an inverted sinking-fund pattern for allocating the insurance expense among the years of coverage would be no more defensible. The imputed interest giving rise to a discount for future costs should logically be offset in full by imputed interest "earned"

7. Id. at 38 . 
on the prepaid amounts. And if imputed interest is to be ignored, the most coherent plan is to spread the cost of the prepaid premium evenly over the years of coverage.

At last it is time to consider accelerated depreciation.

For Kahn, only a short step seems to be involved in the move from blessing an inverse sinking-fund allocation of prepaid expenses to blessing accelerated depreciation. The expenditure to acquire a depreciable asset, he implies, is much like that involved in prepaying an expense such as insurance. ${ }^{8}$ The likeness is perceived more clearly if an expenditure for an asset acquisition is treated as an alternative to renting the asset in question on a year-to-year basis (although the comparative figures need to be adjusted to reflect the fact that the rentals include a return to the lessor for his risk-taking in acquiring the asset and making it available to the lessee). By treating the acquisition of an asset as analogous to prepayment of an expense, Kahn stakes out a position for applying his temporally segmented contract analysis and thereby (mistakenly) arrives at a defense for accelerated depreciation - which can be seen as nothing more than a version of the inverted sinking-fund pattern for allocation of costs among the years.

Taking this path brings Kahn directly up against the analysis of depreciation offered by Marvin A. Chirelstein in his primer on federal income taxation. 9 Chirelstein argues that on the neutrality principle, straight line depreciation is too generous to taxpayers and that only sinking-fund depreciation is theoretically correct if it is assumed that the income stream produced by the asset remains constant throughout its life. ${ }^{10}$ The theory of sinking-fund depreciation, in the words of Kahn, is that "the true depreciation of the [asset] for a given year is the difference between the present value of the remaining income stream, determined at the beginning of the year, and the present value of the remaining income stream, determined at the end of that year." 11 The foundation for this proposition is more easily grasped if it is assumed, not unrealistically, that the market value and thus the cost of acquiring an asset is the present or discounted value of the income stream that the asset is expected to produce for its owner. Working with an illustration structured by Chirelstein, Kahn deals with the case of a machine purchased for

\footnotetext{
8. Id. at 39.

9. M. Chirelstein, Federal Income Taxation (2d ed. 1979).

10. Id. at 135.

11. Kahn, supra note 1 , at 33 .
} 
$\$ 4,000$ at the start of year one. ${ }^{12}$ The purchaser estimates that the machine will produce $\$ 1,200$ of revenue in a lump sum at the very end of each year, for five years, and he does not anticipate that there will be any repair or maintenance expenses in operating the machine or any salvage value. Under these facts the purchaser's expected rate of return on the machine is slightly more than fifteen percent - the discount rate that equates the present value of the expected $\$ 1,200$ per year income stream and the $\$ 4,000$ purchase price (and market value) of the asset. For convenience it is to be assumed that all other potential purchasers of the machine share identical revenue and expense expectations. Fifteen percent can then be treated as the market discount rate associated with ownership of the machine.

To show how sinking-fund depreciation is computed in this case, Chirelstein presents the following schedule:

\begin{tabular}{lcrrrrrrr} 
& $\begin{array}{c}\text { Present Value } \\
\text { of Investment }\end{array}$ & \multicolumn{4}{c}{$\begin{array}{c}\text { Present Value of Remaining } \\
\text { Payment }\end{array}$} & $\begin{array}{r}\text { Annual Loss in } \\
\text { Present Value }\end{array}$ \\
\hline \hline & & 1 & 2 & 3 & 4 & 5 & \\
Start of Year 1 & $\$ 4000$ & $\$ 1045$ & $\$ 905$ & $\$ 790$ & $\$ 687$ & $\$ 573$ & \\
End of Year 1 & 3427 & & 1045 & 905 & 790 & 687 & $\$ 573$ \\
End of Year 2 & 2740 & & & 1045 & 905 & 790 & 687 \\
End of Year 3 & 1950 & & & & 1045 & 905 & 790 \\
End of Year 4 & 1045 & & & & & 1045 & 905 \\
End of Year 5 & $-0-$ & & & & & & & 1045 \\
\hline \hline
\end{tabular}

In connection with the schedule Chirelstein offers an explanation: "The last column shows the true measure of economic cost from year to year and indicates that the correct apportionment method is one which starts low and rises. . . . Income is thus higher in the earlier years than in the later." 13 Recognizing that normally there is considerable difficulty in estimating the net income stream that will be produced by a business asset (a great understatement), and that the income stream often will not remain constant from year to year (another notable understatement), Chirelstein concludes: "In principle, nevertheless, sinking-fund is the only proper method of apportioning the taxpayer's capital investment in accordance with the economic cost of use."14

Kahn's rejection of this reasoning is put succinctly: The fallacy in the sinking-fund concept is that it is premised on an assumption that the exhaustion of one year's useful life of an asset should be offset by the unrealized appreciation in the remaining years of life that arises by virtue of the passage of time. Referring back to

12. Id. at 33 .

13. M. Chirelstern, supra note 9, at 134-35 (emphasis original).

14. Id. at 135 (emphasis original). 
the example above, the last four years of the life of the machine had a greater value after the expiration of one year's time because the revenue for those years was discounted one fewer year. But should that increase in present value affect the determination of the amount of cost to be allocated to the exhaustion of the first year of the machine's useful life? Surely not. The cost of the first year's use is completely unrelated to any unrealized appreciation in the value of the right to use the machine in later years. ${ }^{15}$

In opposition to the Chirelstein position, Kahn emphasizes that "for tax purposes depreciation is a means of allocating a cost that the taxpayer incurred in a prior year. The normal means of allocating cost for an item of property is to determine what amount the owner paid for that item."16 In the case of a depreciable item, he urges that the cost "should be allocated to each year of the asset's use according to the amount paid for that year's use: the amount of income that the taxpayer initially expected the property to produce in that year, discounted to present value as of the date the taxpayer acquired the property."17

Applying this reasoning to the illustrative case, Kahn points out that the cost to be allocated to the first year of the machine's use is $\$ 1,045$; subsequent allocations are $\$ 905$ to the second year, $\$ 790$ to the third, $\$ 687$ to the fourth, and $\$ 573$ to the final year. Thus Kahn once again arrives at an inverted sinking-fund pattern as an acceptable means of apportionment - in short, his approach leads to turning Chirelstein's tabulation precisely upside down. The first year result, as might be expected, is similar to that reached by assuming the taxpayer had rented the machine for one year and had paid in advance for buying the item at the end of that period. The similarity can be extended by envisaging an arrangement consisting of several divisible annual rental terms followed by a purchase, all paid up at the outset. ${ }^{18}$

The ultimate confusion in the Kahn thesis as to accelerated depreciation can now be pinned down. I have already indicated why his temporally segmented cost analysis is wrong in respect to allocating prepaid expenses such as insurance: it simply is unrealistic to divide arbitrarily one contract into several on the assumption that the terms of each will remain unchanged; it is unsophisticated to as-

15. Kahn, supra note 1 , at 34-35.

16. Id. at 35.

17. Id.

18. Id. at 37 . It is interesting to note that Kahn apparently thinks that this result, like the result in the matter of prepaid insurance but unlike the result in the matter of annuity payments, is proper regardless of whether the purchaser reports on the cash receipt or the accrual method. Depreciation method has always been regarded as independent of reporting method. 
sume that our tax system - as loosely jointed as it is - will allow a taxpayer to ignore imputed interest on prepayments while allowing him to claim a discount on those payments for purposes of allocating the expense among different years. The same can be said of using a temporal segmentation approach to arrive at asset acquisition costs that are to be associated with particular years of use. Is there, nevertheless, any force to Kahn's protestation that, under our long-standing tax concept of depreciation, it is always wrong to base depreciation for a particular year on a calculation that takes into account the unrealized appreciation in the residual value of the asset at the expiration of the year under consideration? It undoubtedly is accepted wisdom that the depreciation deduction does not change with a rise in the market value of the asset used in producing income. Must one conclude therefore that sinking-fund depreciation ultimately is at odds with that accepted principle?

Sinking-fund depreciation clearly is not compelled by existing tax doctrines. It is wrong, however, to attribute this outcome to the proposition that unrealized appreciation in the value of an asset is not to be taken into account in computing depreciation. Sinkingfund depreciation need not be explained and justified in terms of seeking to correlate the depreciation deduction with the decline in the value of an asset during the year - although such a correlation will occur under that pattern of depreciation. Another explanation of sinking-fund depreciation is equally persuasive and it possibly might reduce the confusion into which Kahn has fallen.

Return again to annuities and think of a five-year annuity, starting immediately, purchased for a lump sum of $\$ 4,000$. Assume that the interest rate factored into the contract by the annuity company is slightly more than fifteen percent compounded annually. Payments will then be $\$ 1,200$ a year - a total of $\$ 6,000$ over the five years. Based on the analysis of annuities offered earlier, the theoretically "correct" distribution between interest and recovery of cost or investment will be:

\begin{tabular}{ccc} 
Year & Interest & Return of Cost \\
\hline \hline 1 & $\$ 627$ & $\$ 573$ \\
2 & 513 & 687 \\
3 & 410 & 790 \\
4 & 295 & 905 \\
5 & 155 & 1,045 \\
\hline
\end{tabular}

This, of course, is the sinking-fund pattern (and the figures themselves by now should be familiar). 
Sinking-fund depreciation for an asset is based on the same principle and the computation is also the same. Take the illustration of a machine with a five-year life and no salvage value, purchased for $\$ 4,000$ and expected to produce net income of $\$ 1,200$ at the end of each year. If the interest (or discount) rate associated with the machine is fifteen percent compounded annually, the distribution of the $\$ 1,200$ between cost recovery and "profit-over-cost" will exactly track that governing the five-year annuity. In the annuity situation the interest factor reflects the interest credited by the annuity writer. In the machine situation the interest factor reflects the loss of income which could have been earned by the businessman (at an assumed fifteen percent rate) had he elected to invest in another comparable opportunity. The key to the sinking-fund principle in all such situations is imputation of interest.

If an interest factor can be isolated and quantified, then sinkingfund depreciation is theoretically proper because it takes that imputable interest into account. A consequence of reflecting such an interest element is to equate the depreciation deduction for a particular year with the decline in the value of the asset during the year attributable solely to the passage of time. This consequence might well illuminate the case for using sinking-fund depreciation. Misunderstanding, however, can arise if the equation is allowed to overwhelm the point that the sinking-fund notion ultimately rests on the imputation of interest.

In dealing with repayment of loans, the tax system wisely takes into account the rate of interest implicitly agreed upon by borrower and lender, and in the absence of an express agreement between the parties allocating installment payments between principal and interest, the sinking-fund approach is appropriately mandated. In the annuity situation, the sinking-fund approach is theoretically correct; but our lawmakers acted on the practical wisdom of not burdening annuitants with amounts of taxable interest that start high and then decrease. In the case of prepaid expenses, the sinking-fund approach has not been prescribed by the law, probably because as a practical matter it usually is too difficult to determine the interest rate to be imputed for purposes of the computation; in any event, a straight line expensing of the prepaid costs is much simpler to handle. In connection with machines and real property, the law very sensibly has ignored the possibility of confining depreciation to the sinkingfund model. Only in dealing with an extremely narrow and forced set of facts, such as those on which the Chirelstein illustrative case is built, can the imputed interest rate associated with acquisition of the 
asset be derived; and in the real world the facts are almost never so tidy.

In summary: Decelerated or sinking-fund depreciation, which necessarily depends on using an imputed interest factor, cannot be justified as a general prescription because such an interest factor seldom can be plausibly derived. But, in any case, accelerated or inverse sinking-fund depreciation cannot be justified by the neutrality principle. Kahn's argument is based on a gross inconsistency. It assumes wrongly that an imputed interest rate can be found for purposes of discounting the magnitude of costs associated with particular future years. At the same time it ignores altogether the attendant - equally difficult to derive - imputed interest that is associated with prepaying future expenses.

Thus, on the neutrality principle, straight line depreciation generally is the easiest to justify after all. The case for accelerated depreciation, I conclude, must be rested on some other ground. 